\title{
Neuroprotective effects of novel antiepileptic drug lacosamide via decreasing glial activation in the hippocampus of a gerbil model of ischemic stroke
}

\author{
JH Cho ${ }^{1 *}$, CW Park ${ }^{1}$, TG Ohk ${ }^{1}$, MC Shin ${ }^{1}$, YS Kim¹ ${ }^{1}$ MH Won ${ }^{2}$ \\ From ESICM LIVES 2015 \\ Berlin, Germany. 3-7 October 2015
}

\section{Introduction}

Lacosamide, a novel antiepileptic drug, has been discovered to have some beneficial effects beyond its effectiveness.

\section{Objectives and methods}

In the present study, we examined the neuroprotective effect of lacosamide against ischemic damage in the hippocampal CA1 region following $5 \mathrm{~min}$ of transient cerebral ischemia in gerbils using $\mathrm{H}$ \& E staining, NeuN immunohistochemistry and F-J B staining.

\section{Results}

The results showed that pre- and post-treatment with $25 \mathrm{mg} / \mathrm{kg}$ lacosamide significantly protected neuronal death from transient cerebral ischemic injury. Many $\mathrm{H} \& \mathrm{E}$ positive cells, NeuN-immunoreactive neurons and a few number of F-J B-positive cells were found in the stratum pyramidale of the CA1 region in the lacosamide-treated-ischemia-operated groups compared with those in the vehicle-treated-ischemia-operated group. In addition, the treatment with $25 \mathrm{mg} / \mathrm{kg}$ lacosamide markedly attenuated the activation of astrocytes and microglia in the ischemic CA1 region.

\section{Conclusions}

In brief, these results indicate that both pre- and posttreatment with lacosamide can protect CA1 pyramidal neurons from transient cerebral ischemic injury in the hippocampus and the neuroprotective effect of

${ }^{1}$ Kangwon National University, Emergency Medicine, Chuncheonsi, Korea, Republic of

Full list of author information is available at the end of the article lacosamide may be related with decreasing the activation of glial cells in the ischemic CA1 region.

\section{Authors' details}

${ }^{1}$ Kangwon National University, Emergency Medicine, Chuncheonsi, Korea, Republic of. ${ }^{2}$ Kangwon National University, Neurobiology, Chuncheonsi, Korea, Republic of.

Published: 1 October 2015

doi:10.1186/2197-425X-3-S1-A776

Cite this article as: Cho et al:: Neuroprotective effects of novel antiepileptic drug lacosamide via decreasing glial activation in the hippocampus of a gerbil model of ischemic stroke. Intensive Care Medicine Experimental 2015 3(Suppl 1):A776.

\section{SpringerOpen ${ }^{\circ}$}

(c) 2015 Cho et al.; This is an Open Access article distributed under the terms of the Creative Commons Attribution License (http:// creativecommons.org/licenses/by/4.0), which permits unrestricted use, distribution, and reproduction in any medium, provided the original work is properly cited.

Submit your manuscript to a SpringerOpen ${ }^{\circ}$ journal and benefit from:

$\checkmark$ Convenient online submission

- Rigorous peer review

- Immediate publication on acceptance

- Open access: articles freely available online

- High visibility within the field

- Retaining the copyright to your article

Submit your next manuscript at $\boldsymbol{~ s p r i n g e r o p e n . c o m ~}$ 